\title{
JUMLAH ION KROMIUM (Cr) DAN NIKEL (Ni) KAWAT ORTODONTIK STAINLESS STEEL YANG TERLEPAS DALAM PERENDAMAN SALIVA
}

\author{
${ }^{1}$ Ciendy O. Jura \\ ${ }^{2}$ Lydia E. N. Tendean \\ ${ }^{3}$ P. S. Anindita \\ ${ }^{1}$ Kandidat Skripsi Program Studi Pendidikan Dokter Gigi Fakultas Kedokteran \\ ${ }^{2}$ Bagian Biologi Fakultas Kedokteran \\ ${ }^{3}$ Program Studi Kedokteran Gigi Fakultas Kedoktran \\ Universitas Sam Ratulangi Manado \\ Email: indyomegasari@gmail.com
}

\begin{abstract}
Orthodontic stainless steel wire is one of the instrument components oftenly used in orthodontic treatment and may persist in the oral cavity for a long period of time. Orthodontic stainless steelwire in the oral cavity can be corrosive in the presence of $\mathrm{Cr}$ and $\mathrm{Ni}$ ion release which can be harmful to the human body and the stainless steel wire itself. This study aimed to determine the amount of $\mathrm{Cr}$ and $\mathrm{Ni}$ ions released from the stainless steel orthodontic wire that was immersed in artificial saliva. This was an experimental laboratory study with a posttest only control group design. Samples were analyzed by using a UV-Vis spectrophotometry to determine the released $\mathrm{Cr}$ and $\mathrm{Ni}$ ions in the saliva. Samples consisted of 4 brands of orthodontic stainless steel wires immersed in artificial saliva for 30 days with a temperature of $37^{0} \mathrm{C}$. Data were analyzed by using a computer program. The results showed that the release of $\mathrm{Cr}$ ions in samples A, B, C, and D respectively were: $0.302 \mathrm{ppm}, 0.331 \mathrm{ppm}, 0,311 \mathrm{ppm}$, and $0.483 \mathrm{ppm}$ meanwhile of $\mathrm{Ni}$ ions were $1.930 \mathrm{ppm}, 1.778 \mathrm{ppm}, 1.654 \mathrm{ppm}$, and 1.391ppm. Conclusion: The release of $\mathrm{Cr}$ and $\mathrm{Ni}$ ions varied in each sample of orthodontic stainless steel wire .
\end{abstract}

Keywords: orthodontic stainless steel, $\mathrm{Cr}, \mathrm{Ni}$, artificial saliva, UV-Vis spectrophotometry

\begin{abstract}
Abstrak: Kawat ortodontik stainless steel merupakan salah satu komponen alat yang sering digunakan dalam perawatan ortodontik dan dapat bertahan dalam rongga mulut untuk jangka waktu yang lama. Kawat ortodontik stainless steel yang berada di dalam rongga mulut dapat mengalami korosi dengan adanya pelepasan ion $\mathrm{Cr}$ dan Ni yang bersifat merugikan bagi tubuh manusia dan kawat ortodontik itu sendiri. Penelitian ini bertujuan untuk mengetahui besarnya jumlah pelepasan ion $\mathrm{Cr}$ dan $\mathrm{Ni}$ dari kawat ortodontik stainless steel yang direndam dalam saliva buatan. Penelitian ini menggunakan metode eksperimental laboratorium dengan rancangan posttest only control group. Sampel diuji dengan menggunakan spektrofotometri UV-Vis untuk mengetahui pelepasan ion Cr dan Ni dalam saliva. Sampel terdiri dari 4 merek kawat ortodontik stainless steel direndam dalam saliva buatan selama 30 hari dengan suhu $37^{\circ} \mathrm{C}$. Data hasil penelitian dianalisis menggunakan program komputer. Hasil penelitian menunjukkan pelepasan ion Cr pada sampel A, B, C, dan D berturut-turut 0,302 ppm; 0,331 ppm; 0,311 ppm; dan 0,483 ppm sedangkan pelepasan ion Ni 1,930 ppm; 1,778 ppm; 1,654 ppm; dan 1,391 ppm. Simpulan: Pelepasan ion $\mathrm{Cr}$ dan Ni bervariasi dari masing-masing sampel kawat ortodontik stainless steel.
\end{abstract}

Kata kunci : Kawat ortodontik stainless steel, $\mathrm{Cr}$, Ni, saliva buatan, spektrofotometri UV-Vis 
Perawatan ortodontik merupakan salah satu jenis perawatan dibidang kedokteran gigi yang bertujuan untuk mengoreksi ketidakaturan gigi. Perawatan ortodontik mempunyai kendala yaitu waktu perawatan yang relatif lama, sehingga memerlukan suatu komponen alat yang aman dan nyaman serta bisa bertahan dalam rongga mulut dengan jangka waktu yang panjang. ${ }^{1,2}$

Salah satu komponen alat yang digunakan dalam perawatan ortodontik yaitu kawat ortodontik. Terdapat beberapa jenis kawat ortodontik yang dapat dipakai antara lain kawat nickel titanium, stainless steel, $\mathrm{CuNiTi}$, dan beta titanium. Masingmasing kawat memiliki karakteristik yang berbeda-beda. Kawat ortodontik stainless steel merupakan kawat yang paling sering digunakan saat ini dalam perawatan ortodontik. Kawat stainless steel dikenal juga sebagai baja tahan korosi yang mengandung Besi (Fe), Karbon (C), Kromium (Cr), dan Nikel (Ni). Harganya juga lebih ekonomis, namun proses pembuatan yang berbeda-beda dapat memengaruhi tingkat daya tahan korosi kawat stainless steel. $^{2,3}$

Korosi adalah kerusakan atau degradasi logam. Proses terjadinya korosi kawat ortodontik stainless steel di dalam rongga mulut dapat mengakibatkan terlepasnya ion-ion logam yang terkandung di dalam kawat. Ion logam yang terlepas dalam rongga mulut khususnya ion logam Cr dan Ni dapat memberikan dampak yang merugikan bagi kesehatan seperti menimbulkan reaksi alergi, efek toksik dan kariogenik di dalam tubuh manusia., ${ }^{2,4}$

Rongga mulut merupakan lingkungan yang sangat ideal untuk terjadinya biodegradasi logam karena temperatur serta kualitas dan $\mathrm{pH}$ saliva yang dapat memengaruhi kestabilan ion logam. Asam organik dari dekomposisi sisa makanan yang mengandung sulfur juga dapat mendorong terjadinya pelepasan ion $\mathrm{Cr}$ dan $\mathrm{Ni}$ dari kawat ortodontik stainless steel yang begitu lama terendam dalam rongga mulut. $^{2}$

Saat ini sebagian masyarakat masih mempertanyakan keamanan komponen alat ortodontik, khususnya untuk kawat yang paling sering digunakan seperti kawat stainless steel yang memiliki kandungan ion $\mathrm{Cr}$ dan $\mathrm{Ni}$.

Jumlah ion Cr dan Ni merupakan salah satu penelitian awal agar dapat menentukan keamanan dari kawat stainless steel. Berdasarkan latar belakang di atas penulis melakukan uji laboratorik terhadap kadar pelepasan ion $\mathrm{Cr}$ dan $\mathrm{Ni}$ dari kawat ortodontik stainless steel terhadap perendaman saliva.

\section{BAHAN DAN METODE PENELITIAN}

Penelitian ini merupakan penelitian eksperimental laboratorium dengan rancangan posttest only control group. Penelitian ini dilakukan di Laboratorium Kimia Jurusan Gizi Politeknik Kemenkes Manado pada bulan Juli sampai dengan September 2015. Bahan yang digunakan yaitu saliva buatan metode MC Dougal, kawat stainless steel dari produk GAC Pak, American Ortodontik, Ortoorganiser dan Ormco. Pengukuran pelepasan ion $\mathrm{Cr}$ dan Ni dianalisis menggunakan Spektrofotometer UV-Vis dengan satuan ppm. Pada penelitian ini variabel yang digunakan ialah saliva buatan dan pelepasan ion $\mathrm{Cr}$ dan $\mathrm{Ni}$ dari kawat stainless steel.

\section{HASIL PENELITIAN DAN BAHASAN}

Penelitian ini bertujuan untuk mengetahui besarnya jumlah pelepasan ion $\mathrm{Cr}$ dan $\mathrm{Ni}$ dari kawat ortodontik stainless steel yang direndam pada saliva buatan. Jumlah pelepasan ion $\mathrm{Cr}$ dan $\mathrm{Ni}$ diukur pada beberapa jenis kawat ortodontik stainless steel yaitu merek A, B, C dan D, masing-masing terdiri dari 1 sampel disimpan dalam lemari pengeram pada suhu $37^{\circ} \mathrm{C}$ selama 30 hari dan dianalisis atau dilakukan pengukuran dengan menggunakan alat spekrtofotometer UVVis.

Hasil pengukuran yang dilakukan terhadap sampel dari beberapa jenis kawat ortodontik stainless steel dilihat dari ion $\mathrm{Cr}$ (Tabel 1) dan Ni (Tabel 2). 
Tabel 1. Jumlah pelepasan ion $\mathrm{Cr}$ pasca perendaman pada saliva buatan

\begin{tabular}{lcc}
\hline \multicolumn{2}{c}{ Sampel } & $\begin{array}{c}\text { Pelepasan Ion Cr } \\
\text { jumlah(ppm) }\end{array}$ \\
\hline Kontrol & Saliva & 0,000 \\
Perlakuan & A & 0,302 \\
& B & 0,331 \\
& C & 0,311 \\
& D & 0,483 \\
\hline
\end{tabular}

Hasil penelitian uji laboratorium menunjukkan jumlah pelepasan ion $\mathrm{Cr}$ pada kelompok perlakuan kawat ortodontik stainless steel yang direndam pada saliva buatan dengan $\mathrm{pH}$ 6,8. Pelepasan jumlah ion $\mathrm{Cr}$ bervariasi untuk masing-masing sampel.

Tabel 2. Jumlah pelepasan ion Ni pasca perendaman pada saliva buatan

\begin{tabular}{lcc}
\hline \multicolumn{1}{c}{ Sampel } & & $\begin{array}{c}\text { Pelepasan Ion } \\
\text { Ni jumlah (ppm) }\end{array}$ \\
\hline Kontrol & Saliva & $-0,003$ \\
Perlakuan & $\mathrm{A}$ & 1,930 \\
& $\mathrm{~B}$ & 1,778 \\
& $\mathrm{C}$ & 1,654 \\
& $\mathrm{D}$ & 1,391 \\
\hline
\end{tabular}

Hasil penelitian laboratorium menunjukkan, bahwa pelepasan ion $\mathrm{Ni}$ pada beberapa sampel perlakuan kawat ortodontik stainless steel yang direndam dalam saliva buatan dengan $\mathrm{pH}$ 6,8 dan pelepasan dari ion $\mathrm{Ni}$ memiliki perbedaan selisih nilai yang bervariasi serta pada kontrol saliva -0,003 menggambarkan cahaya yang diserap sama dengan kontrol saliva Cr.

Hasil penelitian menunjukkan bahwa telah terjadi pelepasan ion Cr (Tabel 1) dan Ni (Tabel 2) pada beberapa merek kawat ortodontik stainless steel dengan jumlah pelepasan yang bervariasi. Hal ini sejalan dengan penelitian yang dilakukan oleh Aryani $^{2}$ di Balai Besar Laboratorium Kesehatan Jakarta pada tahun 2012 tentang perendaman braket stainless steel. Kristianingsih $^{5}$ di Balai Besar Laboratorium Kesehatan Daerah Surabaya dan Laboratorium sentral FMIPA
Universitas Negeri Malang pada tahun 2013 tentang perendaman kawat ortodontik stainless steel pada minuman berkarbonasi, bahwa terdapat pelepasan ion $\mathrm{Cr}$ dan $\mathrm{Ni}$ yang bervariasi dari setiap merek braket dan kawat ortodontik stainless steel yang direndam dalam saliva buatan maupun minuman berkarbonasi. ${ }^{5}$

Ghom menyatakan bahwa saliva mengandung ion anorganik $\left(\mathrm{N}^{+}, \mathrm{K}^{+}, \mathrm{Cl}^{-}\right.$ dan $\mathrm{HCO}_{3}{ }^{-}$). Komponen anorganik yang berada didalam saliva berperan sebagai media elektrolit yang dapat memicu reaksi elektrokimia. Reaksi elektrokimia merupakan reaksi yang terjadi pada anoda (mengalami oksidasi) dan katoda (mengalami reduksi), dimana ion logam sebagai anoda dan ion $\mathrm{H}^{+}$dari media elektrolit sebagai katoda. Akibat reaksi elektrokimia ini terjadi pelepasan ion $\mathrm{Cr}$ dan Ni dari kawat ortodontik stainless steel sebagai tanda terjadinya korosi. ${ }^{4}$

Jumlah kadar ion $\mathrm{Cr}$ dan $\mathrm{Ni}$ yang terlepas dari 4 merek perlakuan kawat ortodontik stainless steel dapat dilihat pada Gambar 1.

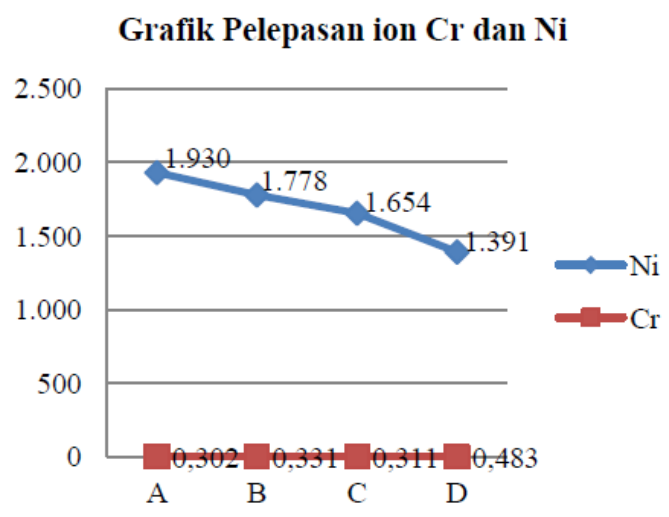

Gambar 1. Jumlah pelepasan ion $\mathrm{Cr}$ dan $\mathrm{Ni}$ berdasarkan 4 merek kawat ortodontik stainless steel.

Pada gambar di atas dapat dilihat bahwa terdapat pelepasan ion $\mathrm{Cr}$ dan $\mathrm{Ni}$ pada ke 4 sampel kawat ortodontik stainless steel tidak memiliki pola dan perbandingan tertentu. Sampel A memiliki pelepasan ion $\mathrm{Ni}$ yang paling banyak, namun memiliki pelepasan ion $\mathrm{Cr}$ yang 
paling sedikit dibandingkan dengan sampel lainnya, begitu pula sampel D yang memiliki pelepasan ion $\mathrm{Ni}$ paling sedikit, namun memiliki pelepasan ion $\mathrm{Cr}$ paling banyak dibanding sampel lainnya.

Hasil penelitian ini berbeda dengan penelitian yang dilakukan oleh Aryani $^{2}$ dimana braket yang direndam memilki pelepasan ion $\mathrm{Cr}$ lebih banyak daripada ion Ni. Hal ini tidak sesuai dengan standar American Iron and Steel Institut (AISI) yang menyatakan bahwa kandungan Cr 18-20\% dan Ni 8\% pada logam stainless steel. Adanya jumlah pelepasan ion $\mathrm{Cr}$ dan $\mathrm{Ni}$ yang bervariasi karena komposisi yang terkandung pada produk kawat ortodontik stainless steel memiliki perbedaan proses pembuatan dari perusahaan masing-masing yang dapat menghasilkan kualitas yang berbeda-beda juga, sehingga dapat memengaruhi tingkat ketahanan korosi dari logam stainless steel. ${ }^{7}$

\section{SIMPULAN}

Hasil penelitian ini menunjukkan bahwa terdapat jumlah pelepasan ion $\mathrm{Cr}$ dan Ni yang bervariasi dari beberapa merek kawat ortodontik stainless steel pada masing-masing sampel A, B, C, dan D.

\section{SARAN}

Dilakukan penelitian serupa untuk mengetahui puncak pelepasan kadar ion $\mathrm{Cr}$ dan Ni berdasarkan waktu perendaman.

\section{UCAPAN TERIMA KASIH}

Penulis menyampaikan terimakasih kepada drg. Michael A. Leman, MMed.Ed, drg. Christy N. Mintjelungan, M.Kes, serta semua pihak yang secara langsung maupun tidak langsung telah memberikan ide dan gagasan dalam penulisan artikel ini.

\section{DAFTAR PUSTAKA}

1. Ardhana W. Buku Ajar Ortodonsia III KGO III. Yogyakarta: Bagian Ortodonsia FKG UGM, 2008; p. 5.

2. Aryani I. Perbandingan tingkat ketahanan korosi beberapa bracket stainless steel ditinjau dari lepasan ION Cr dan Ni. [Tesis]. Jakarta: Universitas Indonesia; 2012.

3. Paramita FT. Deformasi permanen kawat nickel titanium superelastis diameter 0,014 inci pada beberapa produk kawat Ortodonti (penelitian laboratorik) [Tesis]. Jakarta: Universitas Indonesia; 2012.

4. Bardal E. Corrosion and Protection. London: Springer-Verlag, 2004.

5. Kristianingsih R. Analisis pelepasan ion Ni dan Cr kawat ortodontik stainlees steel yang direndam dalam minuman berkarbonasi. Jember: Universitas Jember; 2014.

6. Ghom AD. Textbook of Oral Medicine. Departmen of Oral Medicine and Radiology VSPM dental College. New Delhi: Ajanta Offset \& Packagings Ltd, 2007; p. 564-65.

\section{Lin MC, Lin SC, Lee TH, Huang HH.} Surface analysis and corossion resistance of different stainless steel orthodontic brackets in artificial saliva. Angle Orthod. 2006;76:3229. 